\title{
Fibrous dysplasia of bone
}

INSERM

\section{Source}

INSERM. (1999). Orphanet: an online rare disease and orphan drug data base. Fibrous dysplasia of bone. ORPHA:249

Fibrous dysplasia of bone is a congenital non-hereditary benign bone disease, where normal bone is replaced by a fibrous-like tissue with immature osteogenesis. 